Act ual di stributi on of bacteri ocytes in the trophosone of a bear d wor $\mathrm{m}$ ( $\mathrm{O}$ i gobr achi a mashi koi , Si bogl i ni dae, Annel i da) :

$\mathrm{Cl}$ ar i fi cat i on usi ng whol e- mount i n si tu hybr i di zat i on

\begin{tabular}{|l|l|}
\hline 著者 & $\begin{array}{l}\text { Deguchi M, Kubot a N., Nat suno A. , Kanenor i } \\
\text { M, Fukumbr i Y., Sasayama Yui chi }\end{array}$ \\
\hline $\begin{array}{l}\text { j our nal or } \\
\text { publ i cat i on ti t l e }\end{array}$ & Act a Zool ogi ca \\
\hline vol une & 88 \\
\hline number & 2 \\
\hline page r ange & $129-135$ \\
\hline year & $2007-04$ 01 \\
\hline URL & ht t p: //hdl . handl e. net /2297/6761 \\
\hline
\end{tabular}


In situ hybridisation in beard worm - Deguchi et al.

\title{
Actual distribution of bacteriocytes in the trophosome of a beard worm (Oligobrachia mashikoi, Siboglinidae, Annelida): Clarification using whole-mount in situ hybridisation
}

\author{
M. Deguchi, N. Kubota, A. Matsuno, M. Kanemori, Y. Fukumori and Y. \\ Sasayama ${ }^{2}$ \\ Department of Life Science, Graduate School of Natural Science and \\ Technology, Kanazawa University, Kanazawa 920-1192, Japan; \\ ${ }^{1}$ Department of Biological Science, Faculty of Life and Environmental \\ Science, Shimane University, Matsue 690-0823, Japan; \\ ${ }^{2}$ Noto Marine Laboratory, Institute of Nature and Environmental \\ Technology, Kanazawa University, Kanazawa 920-1192, Japan
}

Key words: beard worms, symbiotic bacteria, 16S rRNA, in situ hybridisation

\section{Abstract}

M. Deguchi, N. Kubota, A. Matsuno, M. Kanemori, Y. Fukumori and Y. Sasayama 2006. Actual distribution of bacteriocytes in the trophosome of a beard worm (Oligobrachia mashikoi, Siboglinidae, Annelida): Clarification using whole-mount in situ hybridisation.-Acta Zoologica (Stockholm)

Beard worms (Siboglinidae, Polycheata) lack a mouth and a digestive tract and harbour chaemosynthetic bacteria in the bacteriocytes of the trophosome. Since beard worms depend on the organic compounds produced by the bacteria for nourishment, the bacteriocytes should be efficient in exchanging various substances with body fluids. For this reason, it is important to determine how the bacteriocytes are organised in the trophosome. As the first step of the present study, the appearance of bacteriocytes was examined in routinely stained paraffin sections. Secondly, visualisation of the actual distribution of the bacteriocytes was attempted using whole-mount in situ hybridisation with a probe of the 16S rRNA nucleotide sequence of the bacterium. After routine haematoxylin and eosin staining, the bacteriocytes appeared to be aligned in cell cords accompanied with nutrient-deposit cells that extended from both sides of the trophosome toward the dorsal side and folded up in the coelomic spaces. In whole-mount preparations, however, bacteriocytes with intense signals of $16 \mathrm{~S}$ rRNA were seen three-dimensionally as many irregular leaves arranged from both sides of the ventral vessel toward the dorsal vessel. 
We will discuss the physiological significance of this characteristic distribution of the bacteriocytes in the present species.

Dr. Y. Sasayama, Noto Marine Laboratory, Institute of Nature and Environmental Technology, Kanazawa University, Kanazawa 920-1192 Japan. E-mail: sasayama@kenroku.kanazawa-u.ac.jp 


\section{Introduction}

Beard worms or Pogonophora lack a mouth and a digestive tract but have a special tissue called the trophosome in the latter half of their extremely slender bodies. In the trophosome, specific cells, named bacteriocytes by Schwemmler (1980), are present. The cytoplasm of the bacteriocyte harbours chaemosynthetic bacteria (Southward et al., 1981; Southward, 1982). Beard worms live on organic compounds produced by the bacteria (Southward, 1993). Therefore, it is important to determine how the bacteriocytes are organised in the trophosome for the exchange of various substances with body fluids.

Some histological studies of the trophosome in vestimentiferan tube worms, which are phylogenetically classified as a sister group of beard worms (Winnepenninckx et al., 1995; Rouse 2001; Halanych 2005), have been conducted. The trophosome of vestimentiferans has been examined histologically in a cold seep tube worm, Lamellibrachia luymesi (van der Land and Norreverg, 1977), and a hydrothermal vent tube worm, Riftia pachyptila (Cavanaugh et al., 1981). Especially in the latter species, research has made significant progress (Gardiner and Jones, 1993; Bright and Sorgo, 2003). The trophosome is minutely composed of 4 concentric circle layers. Bacteriocytes are produced in the centre and degraded in the periphery. It is also known that the glycogen content increases from the centre toward the periphery (Sorgo et al., 2002). Thus, the trophosome in this species is well organised.

On the other hand, Southward (1982) examined 7 species of beard worms and reported that the histology of the trophosome is mutually similar and has a cylindrical shape. An ultrastructural study (Southward 1982, 1993) provided a schematic diagram of the trophosome of Siboglinum

fiordicum (see Fig. 1). The trophosome is made up of an outer layer of nutrient-deposit cells and an inner layer of bacteriocytes separated by a network of blood sinuses lying between the basal lamellae of the two epithelia. It lies between a large dorsal blood vessel and a small ventral blood vessel. In the centre of the trophosome, there is a lumen filled with fluid, which may originate as a gut lumen (Southward, 1993). The outside of the trophosome is surrounded by coelomic fluid (Southward, 1982). In the present species, Oligobrachia mashikoi, the detection of the 16S rRNA of the symbiotic bacteria has been attempted using an in situ hybridisation technique in a paraffin cross section (Kimura et al., 2003), although the nucleotide sequence of the probe was different from that used in the present study. Their study successfully demonstrated the presence of a single endosymbiotic bacterial species in the peripheral portions of the trophosome.

The present study was conducted using the same species, 0 . mashikoi, to demonstrate how the bacteriocytes are organised three-dimensionally 
in the trophosome. At first, a standard staining method using haematoxylin and eosin on paraffin sections was used in addition to techniques of transmission electron microscopy. Following that, a whole-mount in situ hybridisation technique with a probe for the 16S rRNA nucleotide sequence of the symbiotic bacterium was adopted for this purpose.

\section{Materials and Methods}

\section{Routine staining of paraffin sections and transmission electron microscopic techniques}

O. mashikoi specimens were collected as described earlier (Sasayama et al., 2003). The body of the worm was pushed out from its tube with a syringe and fixed in Bouin's solution overnight. The specimens were transferred into $70 \%$ alcohol. The part of the trunk containing the trophosome was cut into about $5 \mathrm{~mm}$ pieces, dehydrated in an alcohol series, and embedded in paraffin wax. The tissue was cut transversely at $10 \mu \mathrm{m}$ thickness and stained with haematoxylin and eosin after removal of the wax.

For the electron-microscopic observation, the part of the trunk containing the trophosome of a living 0 . mashikoi was cut into small pieces about $2 \mathrm{~mm}$ in length and immediately pre-fixed for $120 \mathrm{~min}$. These pieces were washed with a buffer solution several times and post-fixed for $120 \mathrm{~min}$. The composition of the pre-fixative and post-fixative solutions has been described in Matsuno and Sasayama (2002).

Resin-embedded specimens were cut into thin sections with a diamond knife and subsequently stained with saturated aqueous uranyl acetate and lead nitrate. They were then observed with a JEM-1010 electron microscope (JEOL, TOkyo).

\section{Fixation for whole-mount in situ hybridisation}

The worms were fixed with 4\% paraformaldehyde/PBS overnight. The samples were dehydrated, transferred to $100 \%$ ethanol, and preserved at $-20^{\circ} \mathrm{C}$.

\section{RNA probes and its specificity}

A pair of universal primers (27F and 1525r published by Lane (1991)) for amplifying bacterial 16S rRNA gene was synthesised. Total DNA containing the genomic DNA of the symbiotic bacteria was extracted from the present beard worm and used as a PCR template. PCR was used to amplify $1.5 \mathrm{kbp}$ DNA fragments. Those DNAs were cloned into pST Blue-1 (Novagen, Darmstadt) and sequenced with the ABI PRISM 3100 Genetic Analyser (Applied Biosystems, Foster). From one beard worm, only one single sequence was amplified. We registered the 16S rRNA gene (1477bp) to 
the DNA Data Bank of Japan (DDBJ) (accession number: AB252051). The sequences obtained were compared with those of other bacterial 16S rRNA genes, including those of symbiotic bacteria of vestimentiferans, using the GenBank Database of the NIH.

Based on these data, we designed sense and anti-sense RNA probes with the nucleotide sequence corresponding to 18 bases from the 1244 th to the 1261st one (Table 1 ). This portion was not coincident with any other sequences of bacterial 16S rRNA gene on databases, indicating that the anti-sense RNA probe was specific to the 16S rRNA of the symbiont of the present beard worm. The probes were labelled with digoxygenin.

To confirm the specificity of the probes, dot hybridisation was conducted. DNA fragments of the 16S rRNA gene of the symbiotic bacteria of the beard worm used in the present study and of Escherichia coli were heated in boiling water for $8 \mathrm{~min}$ and immediately transferred to ice-water for 5min. Those DNA solutions were spotted separately on a nylon membrane (Hybond-Nplas, Amersham Biosciences Corp., Piscataway, NJ, USA) and fixed with a UV cross-linker (Funakoshi CL-1000, Tokyo) for 2min. To hybridise the DNA fragments with the anti-sense probe, this nylon membrane was incubated in a hybridisation solution composed of 50\% dextran, sulfate/formamide, $4 \times$ SSC, 1 x Denhardt's, $1 \mathrm{mg} / \mathrm{ml}$ yeast tRNA, $10 \mathrm{mM} \mathrm{DTT}$, and $2.5 \mu \mathrm{g} / \mathrm{ml}$ of the DIG-labelled anti-sense probe on a shaker under $55^{\circ} \mathrm{C}$ overnight. Thereafter, the nylon membrane was washed with 4 x SSC four times for $15 \mathrm{~min}$ each time, with a $8.25 \mu \mathrm{g} / \mathrm{ml}$ RNase buffer under $37^{\circ} \mathrm{C}$ for $30 \mathrm{~min}$, with an RNase buffer without RNase for $5 \mathrm{~min}$ twice, with $2 \times \mathrm{SSC} / 10 \mathrm{mM} \mathrm{DTT}$, $1 \times \mathrm{SSC} / 10 \mathrm{mM} \mathrm{DDT}$, and $0.5 \mathrm{xSSC} / 10 \mathrm{mM} \mathrm{DTT}$ for $15 \mathrm{~min}$ each in the order given, and with $0.1 \mathrm{x} \mathrm{SSC} / 10 \mathrm{mM}$ DTT under $55^{\circ} \mathrm{C}$ for $15 \mathrm{~min}$. The treatment with $2 \times \mathrm{SSC}$ was conducted twice for $1 \mathrm{~min}$ each time. Thereafter, the membrane was washed with a blocking buffer for $2 \mathrm{hrs}$ and with the genius buffer-1 for $5 \mathrm{~min}$ twice. This was followed by incubation with anti-DIG-alkaline phosphatase Fab fragments overnight. The next morning, the membrane was washed with genius buffers-1 and -3 , each for 10min, and with a $1 \mathrm{mg} / \mathrm{ml}$ levamisole/genius buffer solution. Finally, the hybridisation with the anti-sense probe was visualised with a BCIP/NBT solution. The colourisation was stopped in a TE solution, which contains eventually Tris-HCl and EDTA at $10 \mathrm{mM}$ and $1 \mathrm{mM}$ concentrations, respectively.

Intense signals were detected by the anti-sense probe only on the spot where the DNA fragments of the 16S rRNA gene of the symbiotic bacteria were dotted (Fig. 2). The spot with the E. coli DNA exhibited no signals. These results demonstrate that the anti-sense probe is useful for the present in situ hybridisation technique.

\section{Whole-mount in situ hybridisation}


Three successive portions of each $5 \mathrm{~mm}$ length of the trunk were cut off. The two ends were utilised for the detection of $16 \mathrm{~S}$ rRNA signals hybridised with the anti-sense probe. The middle piece was adopted as a control hybridised with the sense probe. Before hybridisation, the piece was re-hydrated with 75\% ethanol, 50\% ethanol, and 25\% ethanol for $10 \mathrm{~min}$ each and with PBT (PBS containing triton X-100 at a rate of $0.1 \%)$ for $5 \mathrm{~min}$, in the order given. The tissue was transferred onto the "in situ tip" (Aloka, Tokyo); all subsequent procedures were conducted on this tip on a shaker. First, the tissue was washed with PBT for $5 \mathrm{~min}$. Treatment with a proteinase $\mathrm{K} / \mathrm{PBT}$ solution $(20 \mu \mathrm{g} / \mathrm{ml})$ was conducted for $20 \mathrm{~min}$. After washing with PBT for $5 \mathrm{~min}$ three times, the tissue was re-fixed with a 4\% paraformaldehyde /0.2\% glutaraldehyde/PBT solution for $30 \mathrm{~min}$ and washed again with PBT for $5 \mathrm{~min}$ three times. Subsequently, the pre-hybridisation and hybridisation solutions were prepared as described below. The prehybridisation solution was composed of $50 \%$ formamide, $5 \times$ SSC, a blocking solution, 0.1\% Triton $\mathrm{X}-100,0.1 \% 3-((3-\mathrm{cholamidopropyl})$

dimethylammonio)-1-propanesulphonic acid (CHAPS), $1 \mu \mathrm{g} / \mathrm{ml}$ yeast tRNA, $5 \mu \mathrm{g} / \mathrm{ml}$ heparin, and $10 \mathrm{mM}$ DTT. To the hybridisation solution, a $2.5 \mu \mathrm{g} / \mathrm{ml}$ probe was added. The tissue was washed in the pre-hybridisation solution at $55^{\circ} \mathrm{C}$ for $5 \mathrm{~min}$ and incubated in the new pre-hybridisation solution at $55^{\circ} \mathrm{C}$ for $1 \mathrm{hr}$. Thereafter, the tissue was incubated in the hybridisation solution at $55^{\circ} \mathrm{C}$ overnight. The next morning, the tissue was washed with an SSCFS solution (50\% formamide, $5 \times \mathrm{SSC}, 1 \% \mathrm{SDS}$ ) at $55^{\circ} \mathrm{C}$ for $20 \mathrm{~min}$, with a $2 \times \mathrm{SSCC}$ solution ( $2 \times \mathrm{SSC}, 0.1 \% \mathrm{CHAPS})$ at $55^{\circ} \mathrm{C}$, with a $0.2 \mathrm{xSSCC}$ solution ( $0.2 \times \mathrm{SSC}, 0.1 \% \mathrm{CHAPS})$, and with a KTBT solution (50mM Tris-HCl (pH 7.5), $150 \mathrm{mM} \mathrm{NaCl}, 10 \mathrm{mM} \mathrm{KCl}, 0.1 \%$ TritonX-100) for 10min three times. Thereafter, the tissue was treated with a 1.5\% blocking reagent/KTBT for $1 \mathrm{~h}$. Incubation with an anti-Digoxigenin-AP/1.0\% blocking reagent/KTBT followed overnight. The next morning, the tissue was washed with a KTBT solution for 1 hr five times and treated with an NTMT solution (0.1M NaCl, $0.1 \mathrm{M}$ tris- $\mathrm{HCl}(\mathrm{pH} 9.5), 50 \mathrm{mM} \mathrm{MgCl}_{2}, 0.1 \%$ TritonX-100) for 15min. Furthermore, the tissue was treated for $15 \mathrm{~min}$ with a mixture (1:1) of an NTMT solution and an NTMT-PA solution composed of NTMT with 5\% polyvinyl alcohol. A single treatment with NTMT-PA was repeated twice for $15 \mathrm{~min}$. Finally, hybridisation was visualised with a BCIP/NBT solution under $4^{\circ} \mathrm{C}$ overnight. The colourisation was stopped with PBT. The tissue was washed with PBT for $5 \mathrm{~min}$ five times. In the subsequent steps, excessive colourisation was washed out with an alcohol/PBT series under a light microscope. The tissue was made transparent via a glycerol/PBT series.

\section{Results}


Standard staining of paraffin sections and observation by transmission electron microscopy

Haematoxylin and eosin staining revealed the presence of many cells with many fine granules in the trophosome (Fig. 3). These cells were distributed close to many vacuolated cells. The granulated cells and vacuolated cells were combined to form cell cords that extended from both sides of the ventral portion of the trophosome toward the dorsal side and seemed to be folded within the coelomic cavities (Fig. 3). In addition, a large lumen was observed in the central portion of the trophosome (Fig. 3).

An electron-microscopic study revealed the ultrastructure of the bacteriocytes and nutrient-deposit cells (Fig. 4). The bacteria are slender rods, as in Oligobrachia gracilis and other frenulate pogonophores (Southward, 1982). It became clear that many of the fine granules in the granulated cells are multilayered granules that accumulated in lysosomes in the bacteriocytes (Fig. 4). The vacuoles in the vacuolated cells appear to be the sites of lipid deposits that have dissolved during the preparation process; these vacuoles are visible as large areas of low electron density in the nutrient-deposit cells.

\section{Whole-mount in situ hybridisation}

The middle piece of each fragment of trunk hybridised with the sense probe showed no signals (Fig. 5a). On the other hand, pieces of both ends of each fragment hybridised with the anti-sense probe exhibited intense signals of the presence of 16S rRNA (Fig. 5b). Therefore, the signals show the location of the symbiotic bacteria expressing the $16 \mathrm{~S}$ rRNA, representing the actual distribution of the bacteriocytes. In whole-mount preparations, the bacteriocytes appeared as many irregular leaves arranged on both sides of the ventral vessel and toward the dorsal vessel (Fig. 5b).

\section{Discussion}

The present study revealed that, at least on the basis of standard staining, the location of the bacteriocytes does not fundamentally contradict the schematic diagram of S. fiordicum presented by Southward (1982) or the result of in situ hybridisation using the 16S rDNA probe (Kimura et al., 2003). The ultrastructure of the trophosome in the present study was in agreement with the findings reported by Southward (1982). In O. mashikoi, however, it was clear that the morphology of the trophosome was more complicated than that of $S$. fiordicum. In Fig. 1, the two portions occupied by the bacteriocytes and the nutrient-deposit cells are drawn as neighbouring but still distinct 
tissues. In the present species, however, both types of tissues combine to form cell cords, and two distinct tissues cannot be distinguished by haematoxylin and eosin staining of paraffin sections. Furthermore, taking the results obtained in beard worms so far into consideration, it is suggested that the structure of the trophosome is quite different from that of tube worms. The bacteriocytes of beard worms appeared to be not always held in position when compared to the tightly packed positioning of bacteriocytes in tube worms.

Before designing RNA probes for whole-mount in situ hybridisation, we investigated the probes used in the experiment by Kimura et al. (2003). Previously, Kimura et al. (2001) registered a partial sequence (1508bp) of 16S rRNA gene of the endosymbiont of the present beard worm to the DDBJ (accession number: AB057751). In this sequence, however, 39 unknown bases were contained, corresponding to $2.59 \%$ of the whole sequence. Kimura et al. (2003) suggested, based on the sequence, that the endosymbiont of the present beard worm is the bacterium classified on a branch close to methanotrophic bacteria on a molecular phylogenetic tree. The sequence we obtained was very similar to their sequence but showed subtle differences. The newly obtained sequence without any unknown bases corresponds to the sequence from the 60th to the 1510th bases, which were previously registered by Kimura et al (2001). We also tried to make a cladistic tree with a neighbour-joining method for the new sequence and found that the endosymbiont belongs to the very close position that was reported by Kimura et al. (2003), although it is not clear whether or not the bacterium is a methanotrophic one (Kubota et al., in preparation). Against the background of these facts, we conducted whole-mount in situ hybridization, which provided a specific account of the trophosome structure in comparison to the results by Kimura et al. (2001).

In whole-mount in situ hybridisation, only the bactreiocyte tissue was distinguishable. The actual distribution of bacteriocytes appeared to be in the form of irregular leaves arranged on both sides of the ventral vessel and toward the dorsal vessel. This pattern indicates that nutrient-deposit cells may also be distributed in the same manner. This structure appeared repeatedly in the trophosome. Consequently, on the basis of this information, we drew a three-dimensional schematic diagram (Fig. 6). This characteristic constitution is more practical than the cylindrical structure of the simple double layers of the two cell types because it enlarges the surface area of the bacteriocyte layer in beard worms. That is to say, under the circumstances of inversely directed blood streams of the dorsal vessel and the ventral vessel, which contain various substances, the repeated irregular leaf structure appears to be more advantageous for exchanges of various substances, also from a 
viewpoint of heat flow dynamics, than a simple sheet-like structure. The following phenomena are given as examples: hydrogen sulfide in solution for chemosynthetic symbiotic bacteria, oxygen carried by hemoglobin in the blood for host cells and bacteria, and nutrients produced by the symbiotic bacteria for transfer to nutrient-deposit cells through the blood stream circulating in the dorsal and ventral vessels and probably between the two cell layers, the luminal fluid in the cavity in the middle of the trophosome, and the coelomic fluid in the spaces surrounding the trophosome.

\section{References}

Bright, M. and Sorgo, A. 2003. Ultrastructural reinvestigation of the trophosome in adults of Riftia pachyptila (Annelida, Siboglinidae). Invertebrate Biology, 122: 345-366.

Cavanaugh, C.M., Gardiner, S.L., Jones, M.L. and Jannash, H.W. 1981. Prokaryotic cells in the hydrothermal vent tube worm Riftia pachyptila Jones: Possible chemoautotrophic symbionts. Science 213: 340-342.

Gardiner, S.L. and Jones, M.L. 1993. Vestimentifera. In: Microscopic Anatomy of Invertebrates, vol. 12. Onychophora, Chilopoda, and lesser Protostomata. Harrison, F.W. and Gardiner, S.L. eds., pp. 371-460. Wiley-Liss, New York.

Halanych, K.M. 2005. Molecular phylogeny of siboglinid annelids (a.k.a. pogonophorans): a review. Hydrobiologia 535/536: 297-307.

Kimura, H., Sato, M., Sasayama, Y. and Naganuma, T. 2003. Molecular characterization and in situ localization of endosymbiotic 16S ribosomal RNA and RuBisCo genes in the pogonophoran tissue. Marine Biotechnology 5: 261-269.

Lane, D.J. 1991. 16S/23S rRNA sequencing. In E. Stackebrandt and M. Goodfellow (Eds): Nucleic Acid Techniques in Bacterial Systematics. pp. 115-148. John Wiley and Sons, New York.

Matsuno, A. and Sasayama, Y. 2002. A comparative study of body wall structures of a pogonophore and an annelid from a phylogenetic viewpoint. Zoological Science 19: 695-701.

Rouse, G.W. 2001. A cladistic analysis of Siboglinidae Caullery, 1914 (Polychaeta, Annelida): formerly the phyla Pogonophora and Vestimentifera. Zoological Journal of the Linnean Society 132: 55-80. 
Sasayama, Y., Matada, M., Fukumori, Y., Umebayashi, M., Matsuno, A., Nakagawa, T. and Imajima, M. 2003. External morphology of the posterior end, the "opisthosoma," of the beard worm Oligobrachia mashikoi (Pogonophora). Zoological Science 20: 1411-1416.

Schwemmler, W. 1980. Principles of endocytobiosis: Structure, function, and information. In W. Schwemmler and H.E.A. Schenk (Eds.) : Endocytobiology-Endosymbiosis and Cell Biology, pp. 565-583. De Gruyter, Berlin.

Sorgo, A., Gaill, F., Lechaire, J-P., Arndt, C. and Bright, M. 2002. Glycogen storage in the Riftia pachyptila trophosome: contribution of host and symbionts. Marine Ecology Progress Series, 231: 115-120.

Southward, A.J., Southward, E.C., Dando, P.R., Rau, G.H., Felbeck, H.F. and Flugel, H. 1981. Bacterial symbionts and low 13C/12C ratios in tissue of Pogonophora indicate unusual nutrition and metabolism.

Nature 293: 616-620.

Southward, E.C. 1982 Bacterial symbionts in Pogonophora. Journal of Marine Biolological Association of the United Kingdom. 62: 889-906.

Southward, E.C. 1993 Pogonophora. In F.W. Harrison and M.E. Rice (Eds): Microscopic Anatomy of Invertebrates, vol. 12, pp. 327-369. Wiley-Liss, New York.

Van der Land, J. and Norrevang, A. 1977. Structure and relationships of Lamellibrachia (Annelida, Vestimentifera). Det Kongelige Danske Videnskabernes Selskab Biologiske Skrifer, 21: 1-102.

Winnepenninckx, B., Backeljau, T. and Wachter, R.D. 1995 Phylogeny of protostome worms derived from 18S rRNA sequences. Molecular Biology and Evolution 12: 641-643. 
Table 1

Nucleotide sequences of the probes

Probes Sequence

\begin{tabular}{cl}
\hline Anti-sense & $5^{\prime}-$ CGCCGCCCUCUGUAUGUA $-3^{\prime}$ \\
Sense & $5^{\prime}-$ UACAUACAGAGGGCGGCG $-3^{\prime}$
\end{tabular}




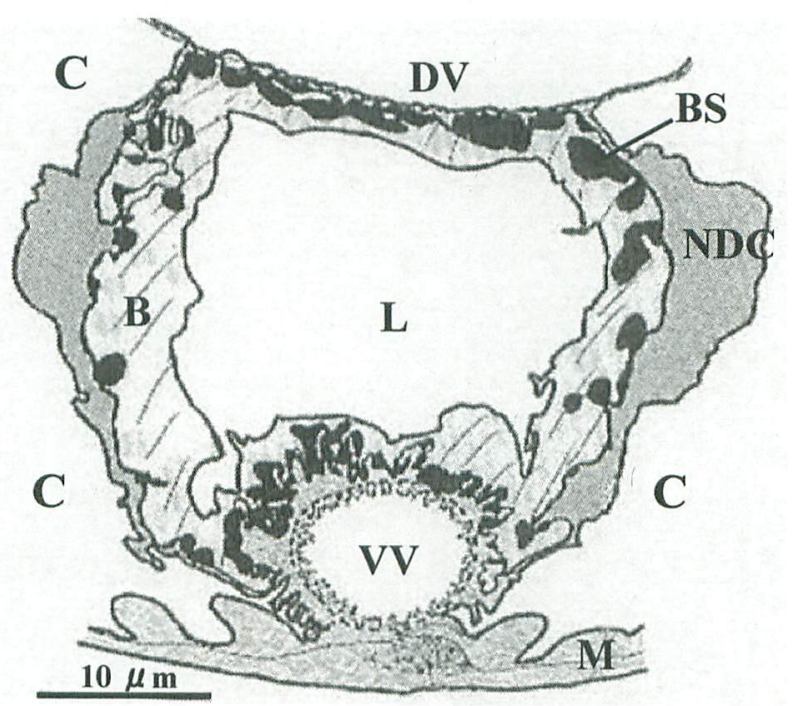

Fig. 1 Schematic diagram of the trophosome in Siboglinum fiordicum redrawn from Southward (1982). B: bacteriocytes; C: coelom; L: lumen; M: muscle; BS: blood space; DV: dorsal vessel; VV: ventral vessel; NDC: nutrient-deposit cells. 


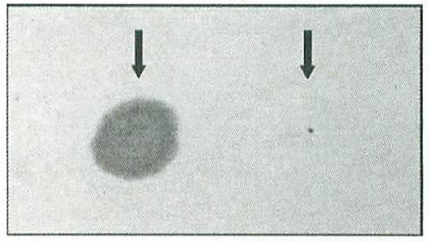

Fig. 2 Dot hybridisation by the anti-sense probe. The left arrow shows the positive reaction of the spot dotted with the DNA fragments of the 16S rRNA gene extracted from the symbiont of the present beard worm. The right arrow exhibits the absence of a positive reaction of the spot dotted with DNA of the 16S rRNA gene from $E$. Coli. 


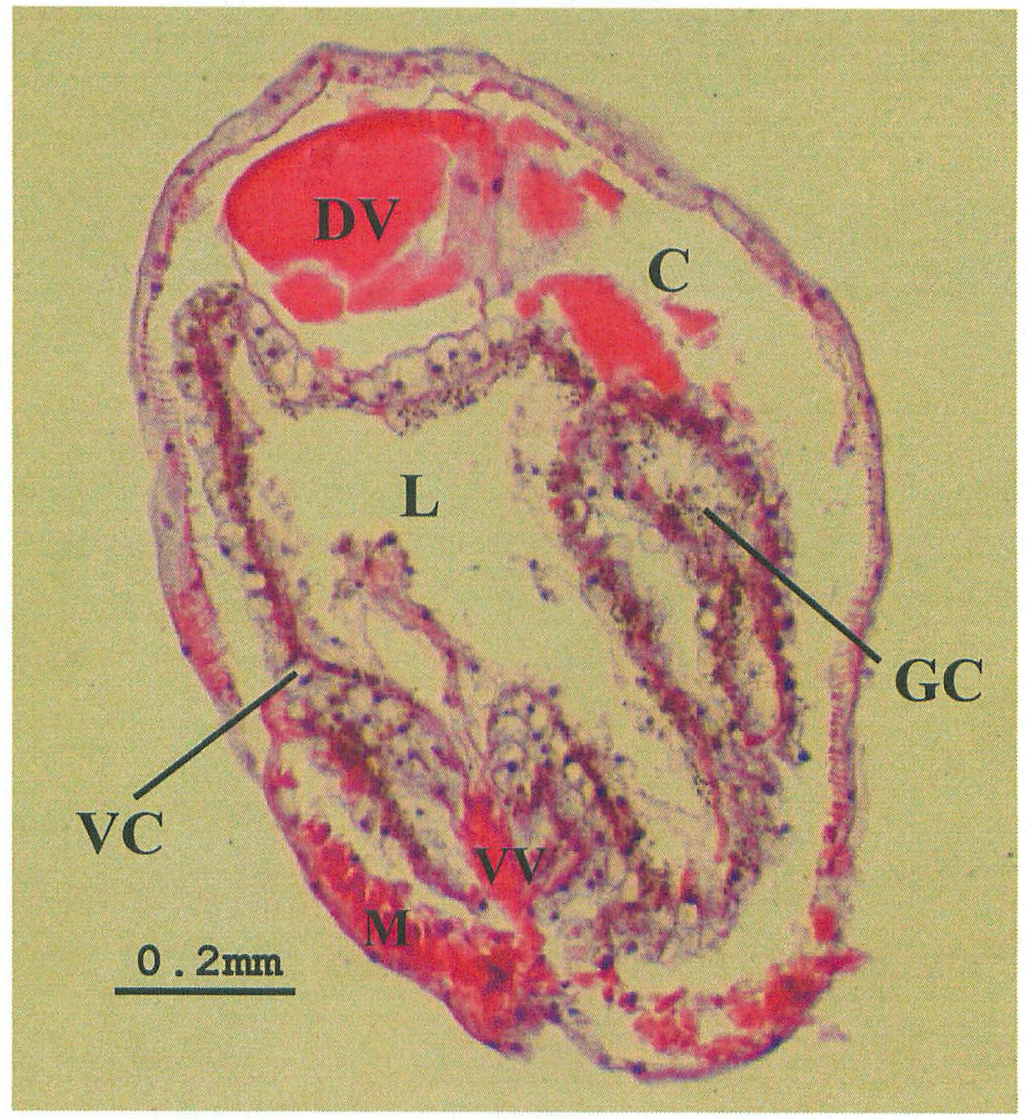

Fig. 3 A standard paraffin section of the trunk of O. mashikoi showing the trophosome stained with haematoxylin and eosin. Note that granulated cells (GC) and vacuolated cells (VC) combine to form a cell-cord structure and fold up in the spaces between the dorsal vessel (DV) and the ventral vessel (VV). C: coelom; L: lumen; M: muscle. 


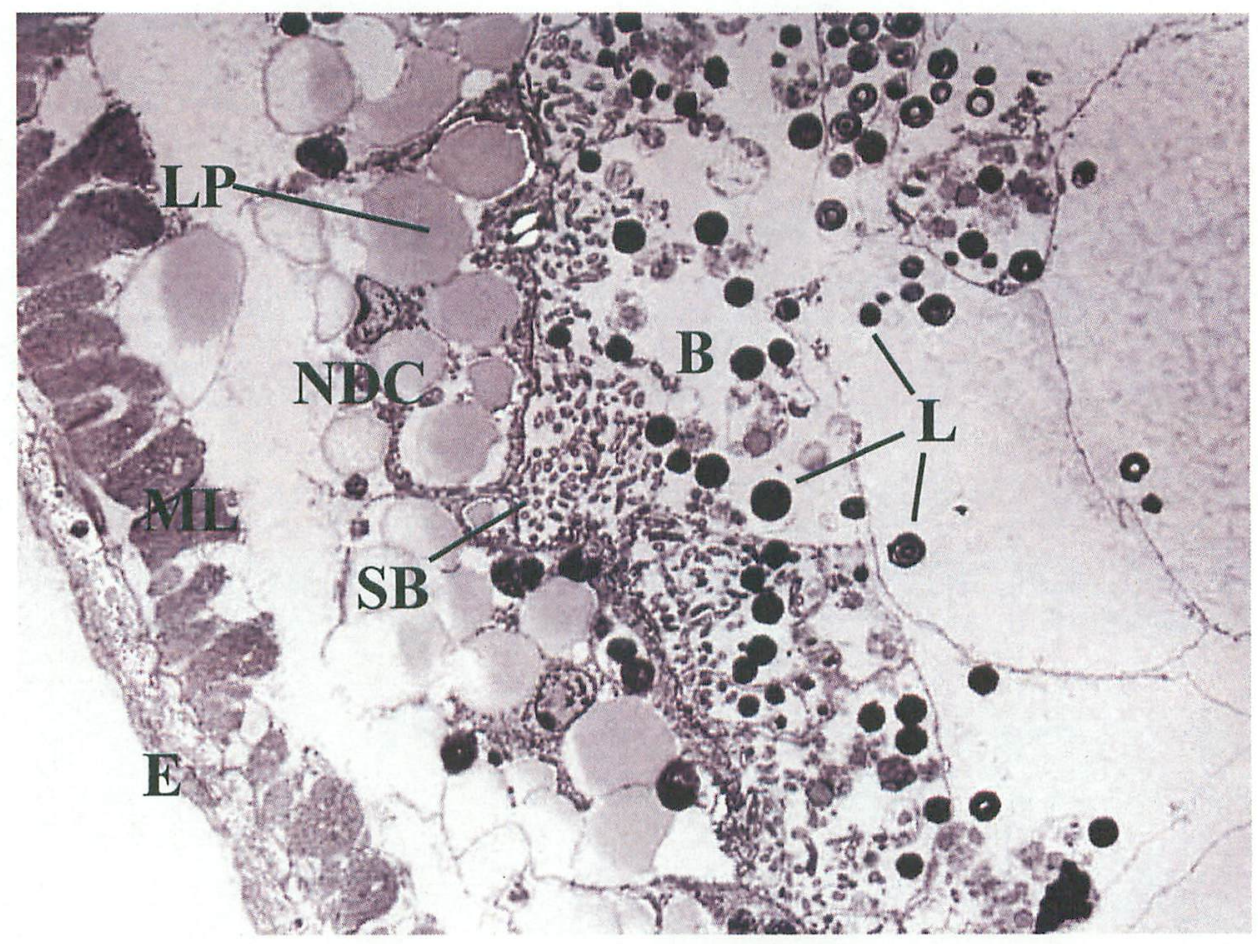

Fig. 4 o. mashikoi. Electron-microscopic photograph of the body wall and trophosome. B: bacteriocytes; E: epidermis; L: lysosomal granule; LP: lipid granules; ML: muscle layer of the body wall; SB: symbiotic bacteria; NDC: nutrient-deposit cells. 

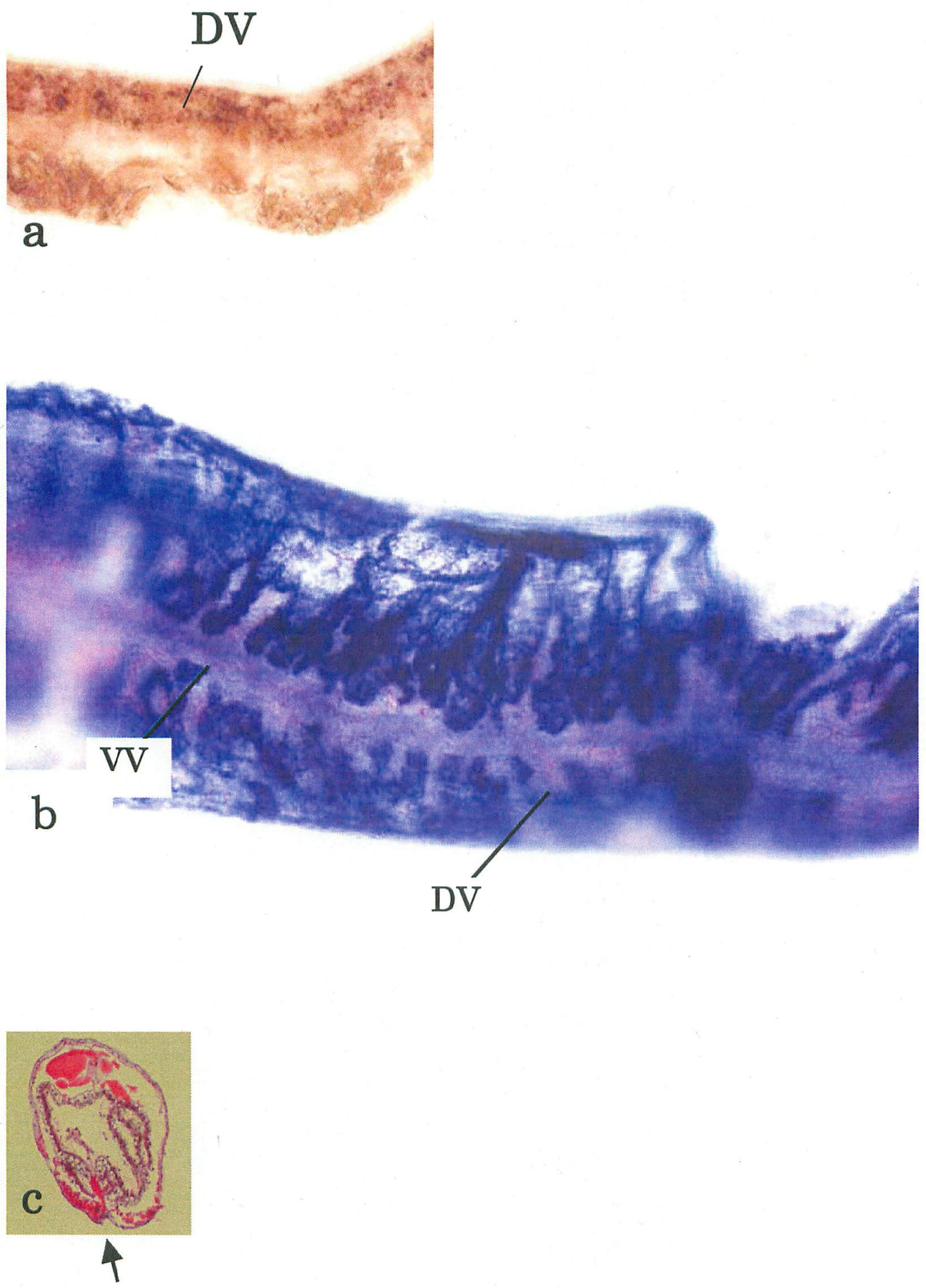

Fig. 5a Whole-mount preparation of the trunk hybridised with the sense probe. The lack of signals is noteworthy. In this preparation, a ventral vessel is not visible. DV: dorsal vessel. 5b whole-mount preparation of the trunk hybridised with the anti-sense probe. This view is from the ventral side of the trunk, as shown by an arrow in Fig. 5c. It is noteworthy that a structure of many irregular leaves is 
indicated by signals on both sides of a fine ventral vessel (VV) under which a vague and thick dorsal vessel (DV) is visible.

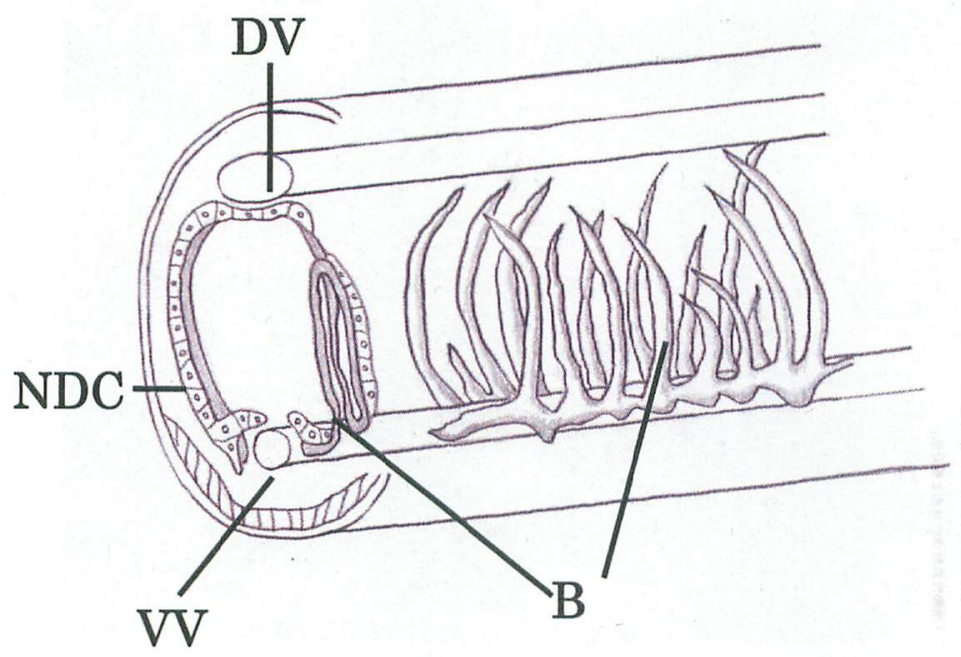

Fig. 6 Three-dimensional schematic diagram of the trophosome in Oligobrachia mashikoi. At the beginning part drawn at the left side, a cell cord composed of bacteriocytes with nutrient-deposit cells is represented. A structure of many irregular leaves shows bacteriocytes signalling the presence of $16 \mathrm{~S}$ rRNA. This structure seems to be a concrete organisation of bacteriocytes in this beard worm. B: bacteriocytes; DV: dorsal vessel; NDC: nutrient-deposit cells; VV: ventral vessel. 